\title{
Psychologické charakteristiky ako prediktory výdavkov turistov: predvýskum u študentov a pilotné overenie u návštevníkov športového podujatia
}

\section{Psychological Characteristics as Predictors of Tourist Spending: Pre-research on a Sample of Students and Pilot Verification in Visitors of a Sporting Event}

\author{
Jozef Džuka" ${ }^{* 1}$, Róbert Štefko ${ }^{2}$ \\ ${ }^{1}$ Filozofická fakulta, Prešovská univerzita v Prešove \\ ${ }^{2}$ Fakulta manažmentu, Prešovská univerzita v Prešove
}

\begin{abstract}
Abstrakt
Vzt'ah osobnosti, motivácie a osobných hodnôt $\mathrm{k}$ výdavkom študentov $(\mathrm{N}=150)$, ktoré súvisia s ich vol’ným časom, bol zist’ovaný pomocou rozsiahleho dotazníka (135 položiek). U žien žiadna z piatich osobnostných vlastností, ani motivácia s výškou výdavkov na vol’ný čas nekorelovala. Regresnou analýzou boli identifikované ako signifikantné prediktory štyri z 19 zist'ovaných osobných hodnôt: hedonizmus, mat' zdroje moci, úsilie o úspešnost' a konformnost' zameraná na dodržiavanie pravidiel. U mužov bola situácia odlišná: signifikantný vzt’ah $\mathrm{k}$ výdavkom mala sociabilita (facet extraverzie) a úzkost' (facet negatívnej emocionality), frustrácia potreby spolupatričnosti a potreby autonómie (dve bazálne psychologické potreby). Na základe týchto analýz bolo možné skrátit' dotazník na 26 položiek. V druhom pilotnom výskume bol zist’ovaný efekt identifikovaných potenciálnych prediktorov výdavkov u návštevníkov športového podujatia $(\mathrm{N}=58)$ skráteným dotazníkom. Očakávané vzt’ahy psychologických charakteristík a výšky výdavkov sa u žien nepotvrdili a u mužov čiastočne: Frustrácia potreby spolupatričnosti a potreby autonómie a hodnota úspešnost' ako ciel', korelovali signifikantne negatívne s výškou výdavkov. Diskutovaný je chýbajúci vzt'ah vel'kej časti zvolených psychologických charakteristík $\mathrm{k}$ výdavkom a uvedené sú východiská pre budúci výskum.
\end{abstract}

Klúčové slová: psychologické charakteristiky, výdavky na vol’ný čas, výdavky turistov.

\begin{abstract}
Psychological research on tourist spending is rare, although econometric research recognizes the importance of unexplored psychological factors. However, psychological variables are missing in the current predictive models of tourist spending in addition to economic,
\end{abstract}

\footnotetext{
* Korešpondenčný autor: Džuka Jozef, Filozofická fakulta, Prešovská univerzita v Prešove, 17. novembra 3724/15, 08001 Prešov, Slovenská republika.

Email: jozef.dzuka@unipo.sk
} 
socio-demographic and travel-related variables. The article presents an attempt to verify personality, motivation and personal values as expenditure predictors. METHOD. Since research involving tourists is organizationally and financially demanding, an investigation of psychological factors related to leisure time of students $(\mathrm{N}=150)$ was carried out first. Following the results of the analyses, the effect of identified potential expenditure predictors of the visitors attending a particular sporting event was tested in a second pilot study involving a smaller sample $(\mathrm{N}=58)$.

Three psychological characteristics of students were investigated using an extensive questionnaire (135 items). On the basis of correlation analysis, it was possible to conclude that none of the five personality traits nor motivation correlated with the level of leisure time spending for women. Using regression analysis, only four of the 19 personality values were identified as predictors: the higher the score for hedonism $(b=.37)$, for the value of having power resources $(b=.16)$ and for the efforts to be successful $(b=.20)$, the higher leisure time spending; compliance with rules was inversely related to leisure time spending $(b=$ $=-.28$ ). For men, the situation was different: sociability (from extraversion) and anxiety (from negative emotionality) were related to the amount of leisure time spending - the higher the sociability rate, the higher the spending, and the higher the anxiety, the lower the spending. The second significant predictor was the frustration of the need for relatedness and the need for autonomy: the higher the frustration of both needs, the lower the spending. Based on these results it was possible to compile a shortened version of the questionnaire, which enabled us to verify the assumption that the identified psychological characteristics related to students' leisure time would be related to the amount of spending among a sporting event visitors. The questionnaire measured 4 values (12 items), 2 facets of personality (8 items), and 2 frustrated needs (6 items) - a total of 26 items. The expected relationships between psychological characteristics and the amount of spending were not confirmed for women, and only partly for men. The frustration of the need for relatedness $(r=-.35)$ and the need for autonomy $(r=-.35)$ as motivation variables and the success value $(r=-.31)$ correlated significantly negatively with the amount of spending: the more frustrated the need for relatedness and the need for autonomy were, the lower the spending rate, and similarly, the more a person was oriented towards personal success, the lower the spending rate. The fact that the identified psychological characteristics for women had no relation to the amount of their spending, and only three of all the characteristics for men had a negative relation to it may be related to the tourism type under study. In other types, such as cultural tourism, nature tourism, etc., the effect of the characteristics examined may be manifested. Therefore, in further research it will be advisable to take into account, for example, the specificity of personal values and the relevant type of tourism. Alternative explanation: the psychological characteristics chosen to have generally low predictive power in relation to spending in all types of tourism, and therefore other psychological characteristics such as, for example, thrift or generosity need to be sought after and tested in a pilot research.

Attempts to propose a predictive model of spending factors in the field of tourism which would include psychological factors of spending are so far dependent on results of further pilot research.

Keywords: psychological characteristics, leisure time spending, spending in tourism.

\section{Problém}

V článku je prezentovaný pokus prispiet’ k výskumu faktorov výdavkov turistov cestovného ruchu, konkrétne k výskumu pravdepodobných činitel'ov výdavkov, ktoré majú povahu trvalej- 
ších psychologických charakteristík osôb. Vzhl'adom na to, že oblast' cestovného ruchu je vel'mi široká, pôjde iba o návštevníkov športového podujatia (športový cestovný ruch - sports tourism, porovnaj napr. Mudarra-Fernandéz, Carrillo-Hidalgo, \& Pulido-Fernández, 2018). Zatial čo čast' faktorov výdavkov v cestovom ruchu je frekventovane skúmaná a pomocou ekonometrických modelov kvantifikovaná (prehl'adne napr. Marcussen, 2011 alebo Thrane, 2014), v doterajších štúdiách sú psychologické premenné ako činitele výdavkov úplne alebo takmer úplne vynechávané. Prípadne sú za psychologické premenné považované tzv. psychografické charakteristiky, ako sú názory alebo hodnotenie cesty (prehl'adne napr. Wang \& Davidson, 2010, Brida \& Scuderi, 2013) alebo motívy v zmysle dôvodov návštevy zvoleného miesta alebo destinácie (napr. Mudarra-Fernandéz et al., 2018). Zároveň však jedným zo záverov týchto štúdií je konštatovanie, že psychologické faktory v predikčných modeloch zohl'adnené neboli a aj ked' sú autormi považované za dôležité, ostáva iba pri odporúčaní alebo požiadavke ich zohl'adnenia v budúcom výskume (napr. Veisten, Lindberg, Grue, \& Haukeland, 2014). S uvedeným stavom poznania súvisí problém nadväznosti na výskum psychologických faktorov výdavkov turistov. Preto sa ako vhodné javilo ako prvý krok realizovat' predbežné pilotné analýzy pravdepodobných psychologických faktorov. Konkrétne, zvážit' ich vol'bu a zvolit' nástroje na ich zist'ovanie, a predovšetkým identifikovat' možnosti redukcie rozsahu dotazníkového opytovania, pretože latentné psychologické charakteristiky sú obvykle zist'ované vel'kým počtom otázok, čo je pre praktický výskum v cestovnom ruchu významným obmedzením.

Ciele tejto práce možno konkretizovat' takto: pretože samotný výskum u turistov cestovného ruchu v jednom, prípadne viacerých typoch cestovného ruchu je organizačne a finančne náročný, prvý ciel' predstavuje identifikovanie pravdepodobných psychologických faktorov výdavkov, ktoré súvisia s vol’ným časom študentov. Druhým ciel’om, v nadväznosti na výsledky týchto analýz, v pilotnom výskume na malej vzorke testovat' efekt identifikovaných pravdepodobných prediktorov výdavkov u návštevníkov konkrétneho športového podujatia. Ide teda o pilotný pokus identifikovat' psychologické premenné a overit’ ich pravdepodobný efekt na výdavky turistov $\mathrm{v}$ jednom type cestovného ruchu.

Štruktúra príspevku: zhrnutie doterajších zistení ohl'adom faktorov výdavkov turistov cestovného ruchu a analýza literatúry týkajúca sa zohl'adnenia psychologických premenných vo výskumoch v oblasti cestovného ruchu, výsledky výskumu výdavkov na vol’ný čas u študentov a výsledky pilotného výskumu výdavkov návštevníkov konkrétneho športového podujatia, celková diskusia a závery vo vzt’ahu k d’alšiemu výskumu.

\section{Faktory ovplyvňujúce výdavky turistov cestovného ruchu}

Prehl'adné analýzy faktorov výdavkov turistov cestovného ruchu publikovali v ostatných rokoch viacerí autori. V tabul'ke 1 uvádzame výsledky analýzy faktorov výdavkov, ktoré boli identifikované v troch štúdiách: Brida a Scuderi (2013), Thrane (2014) a Mudarra-Fernández et al. (2018). 
Tabul'ka 1 Klasifikácia faktorov výdavkov v analyzovaných prácach

\begin{tabular}{lll}
\hline Brida a Scuderi (2013) & Thrane (2014) & Mudarra-Fernández et al. (2018) \\
\hline ekonomické obmedzenia & príjem (domácnosti alebo indivídua) & socio-ekonomické premenné \\
\hline socio-demografické premenné & vek & - \\
\hline psychografické premenné & - & psychologické premenné turistu \\
\hline premenné súvisiace s cestou & vel'kost' skupiny & $\begin{array}{l}\text { premenné týkajúce sa } \\
\text { charakteristiky cesty }\end{array}$ \\
\hline & $\begin{array}{l}\text { dížka pobytu (obvyklý počet } \\
\text { prenocovaní) }\end{array}$ \\
\hline & typ ubytovania (hotel vs iné) \\
\hline & druh dopravy \\
\hline & vzdialenost' \\
\hline & $\begin{array}{l}\text { typ destinácie } \\
\text { (ak je to relevantné) }\end{array}$ \\
\hline & $\begin{array}{l}\text { aktivity v destinácii } \\
\text { (ak je to relevantné) }\end{array}$ \\
\hline & $\begin{array}{l}\text { či bola cesta kúpená ako balík } \\
\text { (ak je to relevantné) }\end{array}$ \\
\hline
\end{tabular}

Zdroj: Vlastné spracovanie.

Brida a Scuderi (2013) uvádzajú štyri skupiny faktorov výdavkov, Thrane (2014) desat' klúčových faktorov výdavkov a Mudarra-Fernández et al. (2018) štyri skupiny faktorov výdavkov turistov. Ekonomické a sociodemografické premenné boli identifikované vo všetkých troch prácach, avšak Mudarra-Fernández et al. (2018) integrovali sociodemografické premenné do skupiny socioekonomických faktorov, preto v tabul'ke nie sú uvedené samostatne. Premenné súvisiace s cestou sú predpokladané vo všetkých troch prácach. Psychologické premenné neuvádza Thrane (2014), zvyšné dve práce ich uvádzajú pod dvoma odlišnými názvami psychografické a psychologické (v Tabul'ke 1 zvýraznené tučným písmom). Čo sa týka psychologických charakteristík, Brida a Scuderi (2013) pod názvom „psychografické“ premenné mali na mysli názory na destináciu a hodnotenie cesty. Mudarra-Fernandéz et al. (2018) pod psychologickými premennými chápali osobnost', dôvody cesty, hodnoty turistov a spokojnost' turistov. K tomu možno poznamenat', že názory, hodnotenie, dôvody cesty a spokojnost' možno považovat' za premenné, ktoré sú situačnej povahy a nie sú trvalou charakteristikou osoby, preto ich v našej analýze nezohl'adňujeme. Za stabilnejšie charakteristiky osoby možno považovat' osobnost' a hodnoty turistu, ktoré boli nájdené v 2 prácach z dvoch odlišných typov cestovného ruchu - oblast' športu (Karvonen \& Komppula, 2013) a pobyty v prírode (Woosnam, Dudensing, \& Walker, 2015). Aj ked' Karvonen a Komppula (2013) použili pojem osobnost', neskúmali osobnost', ale „motivácie“v zmysle dôvody týkajúce sa návštevy pretekov vo veslovaní. Pojem osobnost' predstavuje $\mathrm{v}$ psychologickom výskume iný a špecificky vymedzený obsah a podobne pojem motív a motivácia predstavuje v psychológii odlišný konštrukt ako dôvody. Štúdia autorov Woosnam, Dudensing a Walker (2015) sa týkala špecifickej skupiny turistov, ktorí navštívili konkrétnu oblast' krajiny za účelom prehliadky fauny v jej prirodzenom prostredí. Autori zistili, že emocionálna solidarita ako hodnotová preferencia osôb môže mat’ špecifický efekt na výšku výdavkov v zmysle solidarity s inou krajinou. 
Možno zhrnút', že zo známych a skúmaných faktorov výdavkov turistov cestovného ruchu ani jeden nepredstavuje trvalé psychologické charakteristiky osôb. Výskumy zahŕñajúce psychologické charakteristiky turistov cestovného ruchu boli realizované, avšak netýkali sa výdavkov ale iných aspektov. Išlo predovšetkým o výskumy zamerané na osobnost' turistu, motiváciu a motívy a osobné hodnoty. Preto d’alej stručne uvedieme príklady obvyklých prístupov k definícii a meraniu týchto troch psychologických charakteristík tak, ako sa s nimi možno stretnút' vo výskumoch v oblasti cestovného ruchu všeobecne.

\section{Psychologické charakteristiky ako premenné výskumu v oblasti cestovného ruchu}

\section{Osobné hodnoty turistu}

Li a Cai (2011) skúmali efekt kultúrnych hodnôt na motiváciu k ceste. Použili List of values (LOV; Kahle, 1983), ktorý zist’uje šest' internálnych hodnôt (vrelé vzt’ahy s inými, pocit úspechu, vzrušenie, sebaúcta, byt' rešpektovaným a pocit sebarealizácie) a tri externálne hodnoty (bezpečie, pocit spolupatričnosti a bavit' sa a tešit' sa). Zistili, že internálne hodnoty priamo ovplyvňujú motiváciu poznávat’ a že osoby s touto orientáciou častejšie kupujú výlety. Lin a Fu (2016) použili na výskum hodnôt modifikovaný Rokeachov RVS, avšak na základe vlastných skúseností s dotazníkom odporúčajú využit' iný hodnotový systém, ako je napríklad LOV od Kahle (1983) alebo Schwartz value scale (Schwartz, 1992). Schwartzov (1992) dotazník použili Coppola, Verneau, Caracciolo a Panico (2017) pri výskume osobných hodnôt (ide o 10 bazálnych hodnôt, ktoré môžu byt' opísané prostredníctvom ich motivujúcich ciel’ov: sebaovládanie, stimulácia, hedonizmus, úspech, sila, bezpečnost', konformnost', tradícia, univerzalizmus a benevolencia). Schwartzov model hodnôt (Schwartz, 2012) využili vo svojom výskume návštevníkov zoo a akvárií Ballantyne, Hughes, Lee, Packer a Sneddon (2018).

Možno konštatovat', že v oblasti cestovného ruchu sú osobné hodnoty turistov zriedkavo skúmané a v publikovaných prácach sa objavuje psychologický prístup. Na ich zist’ovanie a interpretáciu autori odporúčajú alebo používajú Schwartzov model hodnôt. V komplexnom modeli výdavkov sa pretojavíbyt'vhodnézohl'adnit'osobnéhodnotyaSchwartzov prístupkichzist'ovaniu.

\section{Motivácia a motívy turistu}

Publikované práce z tejto oblasti frekventovane používajú pomenovanie „motív“ alebo „motivácie“v zmysle dôvody k ceste. Napríklad, Heung, Qu a Chu (2001) alebo De Menezes a Moniz (2011) zist'ovali motívy v podobe názorov na dôvody cesty alebo vlastnosti návštevy (zábava, návšteva priatel’ov...). Psychologický výskum motivácie chápe pojmy motivácia a motív odlišne. Na túto skutočnost' v oblasti výskumu v cestovnom ruchu upozornili vyššie citovaní autori Li a Cai (2011), ktorí skúmali hodnoty a ich vzt’ah k motivácii, presnejšie, k motivačným stavom, ktoré môžu hodnoty vyvolat'. Upozornili, že existuje vel’a psychologických koncepcií motívov a odvolávajú sa na staršiu prácu Murrayho (1964), podl’a ktorého „...motívy sú vnútorné faktory, ktoré podnecujú, riadia a integrujú správanie osoby“ (Murray, 1964, s. 7).“ A dodávajú, že motivácia je produktom interakcie osoby a situácie. Táto predstava je v súlade so súčasným prístupom psychológie k rozlišovaniu motívov a motivácie, ktoré napr. Baumeister (2016) charakterizuje prostredníctvom analógie pojmov dispozícia - tendencia osoby reagovat' pre ňu obvyklým spôsobom a motivačný stav - prechodný stav, ktorý vzniká, ak je príslušný 
motív aktivovaný. Autori vo svojej analýze neskúmali samotné motívy, ale testovali model, v ktorom vnútorné a vonkajšie hodnoty majú efekt na vznik piatich typov motivácie (v zmysle motivačných stavov) a súčasne majú priamy a mediovaný vzt’ah k behaviorálnej intencii. Lichy a McLeay (2018) publikovali výsledky výskumu, ktorý sa týkal motivácie k ceste u tzv. „,bleisure travelers“. Kriticky sa vyjadrili k stavu chápania motivácie a motívov v literatúre z oblasti cestovného ruchu kvôli zložitosti a nejednoznačnosti psychologických faktorov a kvôli t’ažkosti s meraním nepozorovatel'ných premenných. Autori opisujú vlastný postup zist'ovania ,generic motivations and types of bleisure travelers", ktorý však nie je v žiadnej väzbe na existujúce prístupy $\mathrm{k}$ výskumu motivácie $\mathrm{v}$ oblasti cestovného ruchu, ani k psychologickej teórii motivácie. V skutočnosti nešlo o zist'ovanie motivácie ani motívov v intenciách psychologického chápania týchto konštruktov ale o motivácie, motívy v zmysle dôvodov $\mathrm{k}$ ceste.

Zatial' čo v prípade osobných hodnôt existuje v oblasti výskumu cestovného ruchu vhodné východisko ich definovania a merania, v prípade motívov je situácia menej priaznivá. Integrovanie motívov, ako psychologických premenných výdavkov turistov na základe existujúcich prístupov v oblasti výskumov v cestovnom ruchu, sa javí byt' nedostatočne teoreticky a metodologicky pripravené. V tejto práci sme sa rozhodli pre prístup sebadeterminačnej teórie k motivácii (napr. Deci \& Ryan, 2000), ktorá predpokladá existenciu troch bazálnych psychologických potrieb - spolupatričnosti, kompetencie a autonómie (podrobne napr. Džuka, 2019).

\section{Osobnost' turistu}

V literatúre z oblasti turizmu možno evidovat' postupnú orientáciu na aktuálne dominujúci prístup psychologickej vedy k definícii osobnosti a zist'ovaniu jej stabilných čŕt.

V psychologickej literatúre počas posledných niekol'kých rokov dominuje meranie piatich stabilných osobnostných vlastností a frekventovane sa používa IPIP-NEO personality inventory. Iný nástroj, ktorý meria pät' faktorov osobnosti, použili Tan a Tang (2013), ktorí skúmali pomocou Big Five inventára, ako osobnost' ovplyvňuje vyhl'adávanie informácii súvisiacich s cestovným ruchom. Konkrétne použili 44-item BFI (Big Five Inventory) autorov John a Srivastava (1999), 10 itemov zist'uje otvorenost' voči zážitkom, 9 itemov svedomitost', 8 itemov extraverziu, 9 itemov znášanlivost' a 8 itemov neurotizmus. Iní autori, Chen, Yu, Chang a Hsieh (2014) skúmali tzv. „,backpacking“ cestovanie. Na meranie piatich osobnostných čŕt (trait) použili 26 itemov dotazníka „Big Five“ autorov Costa a McCrae (1992). Z výsledkov ich štúdie vyplynulo, že osobnostné vlastnosti významne ovplyvňujú životný štýl a vzdelávacie cesty. Jani (2014) použil 22 položiek BFF (Big Five Factors) na výskum vzt’ahu osobnosti a aktivít, ktoré súvisia s cestou. Z uvedeného je vidiet', že aj ked' vo všetkých výskumoch bol použitý rovnaký prístup k meraniu, autori používajú odlišný názov a hlavne, v každom výskume bol použitý rozdielny počet položiek, ktoré tvoria pät' meraných faktorov. A vec sa ešte komplikuje tým, že iní autori, napr. Kim, Bonn, Lee a Hahn (2018) pracujú so skratkou OCEAN, ktorá rovnako predstavuje pät' charakteristík osobnosti (Otvorenost', Svedomitost', Extraverzia, Znášanlivost' a Neurotizmus), ktoré sú známe aj pod skratkami NEO alebo BIG5.

Zhrnutie. Po prvé, pre psychologické premenné je vo výskumoch v cestovnom ruchu používané pomenovanie ,psychografické premenné“ a pomenovanie ,,psychologické charakteristiky turistu“ - druhé korešponduje s terminológiou psychologickej vedy. Po druhé, žiadny z analyzovaných výskumov z oblasti cestovného ruchu, ktorý zohl'adňoval psychologické premenné, neoveroval ich efekt na výdavky turistov. Po tretie, s výnimkou motivačného systému, osob- 
nost' a osobné hodnoty boli v analyzovaných prácach čiastočne, resp. dostatočne kompatibilné s prístupom psychologickej vedy k týmto premenným. Na základe uvedeného možno konštatovat', že v komplexnom modeli výdavkov turistov cestovného ruchu možno zohl'adnit' tri vyššie opísné psychologické charakteristiky osoby a s výnimkou prístupu k motívom a motivácii aplikovat' prístupy, ktoré sú využívané v súčasnom výskume cestovného ruchu.

\section{A) Pilotný výskum faktorov výdavkov na vol’ný čas u študentov}

V úvode sme uviedli, že výskum u turistov v jednom alebo viacerých typoch cestovného ruchu je organizačne a finančne náročný, a preto sme sa rozhodli preskúmat' najprv pravdepodobné psychologické faktory výdavkov, ktoré súvisia s vol'ným časom študentov. Výskumy výdavkov u študentov na Slovensku podl'a našich vedomostí vo vedeckých časopisoch neboli publikované, avšak bol nájdený jeden výskum publikovaný v odbornom časopise. Išlo o výskum Angeloviča a Harizal (2015), ktorí analyzovali viaceré aspekty výdavkov 102 študentov jedného študijného odboru s dôrazom na ich výšku v závislosti od miesta bydliska študentov. Z viacerých analyzovaných článkov publikovaných v zahraničí bolo možné zistit', že výskumy výdavkov kladú dôraz na rôzne aspekty, ktoré s faktormi výdavkov nesúvisia alebo súvisia iba okrajovo. Napríklad Hermannsson, McGregor a Swales (2013) navrhli všeobecný model výdavkov na spotrebu s tým, že ilustrujú jeho aplikáciu u vysokoškolských študentov v Škótsku. Uvádzajú, že študenti sú pre test tohto modelu obzvlášt' užitočným príkladom. Avšak dôraz ich výskumu je orientovaný na pôvod prostriedkov v závislosti od toho, či ide o domácich alebo zahraničných študentov, nie na model determinácie výdavkov v závislosti od vlastností osoby. Jalil, Yusof, Rambeli, Samsudin a Zakariya (2015) skúmali manažovanie osobných výdavkov študentov, resp. vlastného rozpočtu, ktorým disponujú. Aj v tomto prípade však išlo o výskum úspor na základe príjmov a výdavkov, nie o faktory, ktoré ovplyvňujú výšku výdavkov. Zhang a Ren (2016) skúmali výdavky čínskych vysokoškolákov a aj ked' sami tvrdia, že išlo im o hl'adisko mentality študentov, nie o ekonomické aspekty, pod mentalitou chápali praktickú užitočnost' kupovanej veci, módnost', značkové veci, cenu a iné. Štruktúru výdavkov 150 zahraničných študentov na univerzite v Malajzii s ciel'om identifikovat' ich potenciál ako kúpnej sily pre jednotlivé oblasti skúmali Sallahuddin, Zalila, Noor Sa'adah, Zalina a Mohamad (2018). Konkrétne išlo o výdavky do 14 rôznych oblastí (napr. na jedlo, oblečenie, benzín, bývanie...) s tým, že jednou z oblastí bola rekreácia, zábava a vol’ný čas. Faktory, ktoré tieto výdavky ovplyvňujú však autori neskúmali. Môžeme uzavriet', že je to jedna z mála takto zameraných štúdií, ktoré boli publikované za posledných 10 rokov a ktoré bolo možné nájst' v databáze scholar google https://scholar.google.com/.

\section{Metóda}

\section{Vzorka}

Výskumnávzorkapredstavovala 176študentov,znich24boloinejštátnejpríslušnostiakoslovenskej a 2 osoby neuviedli štátnu príslušnost'. Poznámka: išlo o 24 zahraničných študentov, u ktorých bolo riziko nepresného porozumenia použitých psychologických škál v slovenčine. Po vylúčení týchto 26 osôb predstavoval analyzovaný výskumný súbor 150 slovenských vysokoškolských študentov vo veku $\mathrm{M}=20.58$ rokov (18-25 rokov), z toho 41 (27.3 \%) mužov. Z celkového počtu opytovaných 56 bývalo na internáte, 79 doma a 15 uviedlo ako odpoved' možnost' „inde“. 
Nástroje

Okrem základných sociodemografických informácií (štátna príslušnost’, rod, vek v rokoch a typ bývania - internát, doma a inde) boli zist'ované:

približná mesačná výška výdavkov na vol’ný čas, zábavu (stupnica: menej ako $20 €=1$, $20-30 €=2,30-40 €=3,40-50 €=4$ a viac ako $50 €=5)$

približná mesačná výška celkových nevyhnutných výdavkov (menej ako $100 €=1$, $100-200 €=2,200-300 €=3$, viac ako $300 €=4)$.

približná mesačná výška všetkých prostriedkov počas semestra (menej ako $50 €=1$, $50-100 €=2,100-150 €=3,150-200 €=4,200-250 €=5$, viac ako $250 €=6$ ).

\section{Psychologické charakteristiky}

\section{Osobnost}

Na zistovanie osobnostných premenných bolo použitých 5 škál dotazníka BFI-2 (Soto \& John, 2017, slovenský preklad Halama \& Kohút), ktoré reprezentujú 5 domén, pričom každá z domén je tvorená troma facetami (v zátvorke): Extraverzia (sociabilita, asertivita, energetická úroveň), Prívetivost' (súcit, zdvorilost', dôvera), Svedomitost' (organizovanost', produktivita, zodpovednost'), Negatívna emocionalita (úzkost', depresia, emocionálna nestálost') a Otvorenost' (intelektuálna zvedavost', estetická senzitivita a kreatívna predstavivost'). Odpoved'ová stupnica: 1 = vel'mi nesúhlasím, 5 = vel’mi súhlasím. Príklady položiek dotazníka neuvádzame - celý dotazník je dostupný na: http://www.colby.edu/psych/wp-content/uploads/sites/50/2013/08/bfi2-form-slovak.pdf.

\section{Motivácia}

Na zist'ovanie uspokojenia, resp. frustrácie troch základných psychologických potrieb bol použitý 18-položkový dotazník BPMN (Balanced Measure of Psychological Needs scale, Sheldon \& Hilpert, 2012, slovenský preklad Džuka, 2019). Každá z 3 škál má 6 položiek: Spolupatričnost', napr. položka „Zažíval/a som blízkost' l’udí, ktorí sa o mňa zaujímajú a o ktorých sa zaujímam ja“, Kompetencia, napr. položka „Aj vel'mi t’ažké veci som urobil/a dobre“ a Autonómia, napr. položka „Mal/a som slobodu urobit’ veci tak, ako som ja sám/a chcel/a“. Vzhl’adom na to, že v slovenskej verzii nebolo možné potvrdit’ trojfaktorovú štruktúru, ale boli identifikované 2 faktory - uspokojenie vs. frustrácia všetkých troch bazálnych psychologických potrieb (porovnaj napr. Cordeiro, Paixao, Lens, Lacante, \& Sheldon, 2016), vyhodnocovali sme dve škály uspokojenie a frustrácia základných psychologických potrieb. Odpoved’ová stupnica: 1 = vôbec to nie je pravda, 7 = úplne je to pravda.

\section{Hodnoty}

Na zist'ovanie hodnôt bol použitý 57-položkový dotazník PVQ5X Value Survey (Schwartz et al., 2012), ktoré sú autormi dotazníka považované za motivujúce ciele. Konkrétne ide o týchto 19 hodnôt - motivujúcich ciel'ov: 1) Chciet' sa zlepšovat', 2) Bezpečnost' spoločnosti, 3) Hedonizmus, 4) Konformnost' v interpersonálnych vzt'ahoch, 5) Univerzalizmus - spravodlivost', 6) Dominujúca moc, 7) Pokora, 8) Univerzalizmus - ochrana prírody, 9) Zachovanie si vlastnej tváre, 10) Stimulácia, 11) Zhovievavost' - spol'ahlivost', 12) Osobná bezpečnost', 13) Mat' zdroje moci, 14) Univerzalizmus - tolerantnost', 15) Konformnost' - dodržiavanie pravidiel, 16) 
Úspešnost', 17) Zachovávanie tradícií, 18) Zlepšovanie vlastnej akčnosti, 19) Zhovievavost' starostlivost'. Položky sú formulované ako opisy osoby, napríklad položka č. 3, ktorá zist'uje hedonizmus: „Mat' sa dobre, je pre ňu dôležité“. Osoby odpovedajú na 6-bodovej odpoved’ovej stupnici: 1 = vôbec nie je ako ja, 6 = je úplne ako ja.

\section{Realizácia výskumu}

Výskum sa uskutočnil v mesiaci február 2019 počas vyučovania na jednej z fakúlt v Prešove. Odpovedanie na otázky v dotazníkoch trvalo 30-45 minút. Študenti boli v inštrukcii oboznámení so zámerom výskumu a informovaní, že ich odpovede sú anonymné a budú použité iba na účely výskumu. Analýza dát bola realizovaná pomocou IBM SPSS Statistics 20.

\section{Výsledky}

Deskriptívna a korelačná analýza

Tabul'ka 2 Priemery (M), štandardné odchýlky (SD) a bivariantné korelácie v celej vzorke $(N=150)$

\begin{tabular}{|c|c|c|c|c|c|}
\hline & M & SD & 1. Vol'ný čas & 2. Nevyhnutné & 3. Prostriedky \\
\hline 1. Výdavky na vol'ný čas & 3.70 & 1.40 & - & - & - \\
\hline 2. Výdavky nevyhnutné & 2.59 & 1.05 & $.42 * *$ & - & $.39 * *$ \\
\hline 3. Prostriedky celkom & 4.19 & 1.65 & $.44 * *$ & - & - \\
\hline \multicolumn{6}{|l|}{ Osobnost' } \\
\hline 4. Extraverzia & 3.57 & 0.59 & $.20^{*}$ & $.20 * *$ & $.19^{*}$ \\
\hline 5. Prívetivost' & 4.30 & 0.57 & -.04 & -.09 & -.03 \\
\hline 6. Svedomitost' & 4.12 & 0.60 & -.11 & -.01 & -.02 \\
\hline 7. Negatívna emocionalita & 3.41 & 0.66 & -.11 & .01 & $-.17 *$ \\
\hline 8. Otvorenost' & 4.00 & 0.59 & .10 & .15 & .10 \\
\hline \multicolumn{6}{|l|}{ Motivácia } \\
\hline 9. Uspokojenie potrieb & 5.36 & 0.77 & -.01 & .14 & $.18^{*}$ \\
\hline 10. Frustrácia potrieb & 3.77 & 1.32 & -.09 & .02 & -.09 \\
\hline \multicolumn{6}{|l|}{ Hodnoty } \\
\hline 11. Chciet' sa zlepšovat' & 4.32 & 0.94 & -.07 & $.20 *$ & .04 \\
\hline 12. Bezpečnost' spoločnosti & 4.06 & 1.01 & -.03 & .02 & .10 \\
\hline 13. Hedonizmus & 4.76 & 0.83 & $.29 * *$ & $.18 *$ & .08 \\
\hline 14. Konformnost' interperson. & 4.16 & 1.08 & .04 & .05 & -.06 \\
\hline 15. Univerzalizmus spravod. & 4.46 & 1.00 & -.06 & .09 & -.05 \\
\hline 16. Dominujúca moc & 2.78 & 1.22 & .11 & .11 & .04 \\
\hline 17. Pokora & 4.15 & 0.95 & -.10 & -.09 & -.11 \\
\hline 18. Univerzalizmus príroda & 3.62 & 1.19 & -.03 & .09 & .07 \\
\hline 19. Zachovat' si tvár & 4.25 & 1.01 & .08 & .12 & .07 \\
\hline 20. Stimulácia & 4.12 & 0.95 & .16 & $.28^{* *}$ & .14 \\
\hline 21. Zhovievavost' - spol'ah. & 4.83 & 0.85 & .06 & .08 & .03 \\
\hline
\end{tabular}




\begin{tabular}{llllll}
\hline 22. Osobná bezpečnost' & 4.50 & 1.08 & -09 & -.04 & -.09 \\
\hline 23. Mat' zdroje moci & 3.17 & 1.37 & $.22^{* *}$ & $.18^{*}$ & $.16^{*}$ \\
\hline 24. Univerzalizmus tolerant. & 3.95 & 0.88 & .04 & $.17^{*}$ & -.02 \\
\hline 25. Konformnost' pravidlá & 3.24 & 1.02 & $-.29^{* *}$ & -.11 & -.19 \\
\hline 26. Úspešnost' & 4.07 & 1.04 & $.23^{* *}$ & $.25^{* *}$ & $.16^{*}$ \\
\hline 27. Zachovávanie tradící́ & 3.73 & 1.24 & -.09 & .01 & .08 \\
\hline 28. Vlastná akčnost' & 4.73 & 0.85 & .02 & $.28^{* *}$ & $.18^{*}$ \\
\hline 29. Zhovievavost'-starostliv. & 5.20 & 0.76 & .03 & .07 & .05 \\
\hline
\end{tabular}

V tabul'ke 2 sú uvedené základné deskriptívne údaje (M, SD) a korelácie skúmaných psychologických charakteristík s výdavkami na vol’ný čas, s nevyhnutnými výdavkami a celkovými prostriedkami, ktorými osoba disponuje. Všetky premenné s výnimkou Zhovievavost'-starostlivost' (skew $=-1.32$ ) boli normálne rozložené. Ako je z tabul'ky vidiet', tri druhy výdavkov navzájom spolu vysoko významne korelujú. Objektom záujmu boli korelácie psychologických charakteristík a výdavkov na vol'ný čas - ukázalo sa, že iba 5 z 26 analyzovaných psychologických charakteristík boli v signifikantom vzt’ahu: Extraverzia ( $\mathrm{r}=$ $=.20)$, Hedonizmus $(\mathrm{r}=.29)$, Mat' zdroje moci $(\mathrm{r}=.22)$, Konformnost' - dodržiavanie pravidiel $(\mathrm{r}=-29)$ a Úspešnost' $(\mathrm{r}=.23)$. Č́m vyššie skóre v extraverzii, hedonizme, disponovaní zdrojmi moci a úspešnosti, tým vyššie výdavky na vol'ný čas. Konformnost' je v negatívnom vzt'ahu vyššie skóre znamená nižšiu mieru výdavkov na vol'ný čas.

V tabul'ke 3 uvádzame výsledky korelačnej analýzy psychologických premenných a výdavkov na vol'ný čas pre ženy a mužov zvlášt'.

Tabul'ka 3 Bivariantné korelácie výdavkov na vol'ný čas u žien $(n=109)$ a mužov $(n=41)$

\begin{tabular}{|c|c|c|}
\hline \multirow[b]{4}{*}{ 1. Extraverzia } & \multicolumn{2}{|c|}{ Výdavky } \\
\hline & Ženy & Muži \\
\hline & \multicolumn{2}{|c|}{ Osobnost' } \\
\hline & .14 & $.33^{*}$ \\
\hline 2. Prívetivost' & .01 & -.20 \\
\hline 3. Svedomitost' & -.14 & -.05 \\
\hline 4. Negatívna emocionalita & -.01 & $-.39 *$ \\
\hline \multirow[t]{2}{*}{ 5. Otvorenost' } & .08 & .14 \\
\hline & \multicolumn{2}{|c|}{ Motivácia } \\
\hline 1. Uspokojenie potrieb & -.08 & .18 \\
\hline \multirow[t]{2}{*}{ 2. Frustrácia potrieb } & .04 & $-.38 *$ \\
\hline & \multicolumn{2}{|c|}{ Hodnoty } \\
\hline 1. Chciet' sa zlepšovat' & $-.21 *$ & .20 \\
\hline 2. Bezpečnost' spoločnosti & -.00 & -.11 \\
\hline 3. Hedonizmus & $.30^{* *}$ & .26 \\
\hline 4. Konformnost'-interpersonálne v. & .05 & .03 \\
\hline 5. Univerzalizmus spravodlivost' & -.06 & -.08 \\
\hline 6. Dominujúca moc & .14 & .05 \\
\hline
\end{tabular}




\begin{tabular}{lcc}
\hline 7. Pokora & -.13 & -.05 \\
\hline 8. Univerzalizmus príroda & -.05 & .01 \\
\hline 9. Zachovat' si tvár & .12 & -.04 \\
\hline 10. Stimulácia & .09 & .29 \\
\hline 11. Zhovievavost' - spol'ahlivost' & -.03 & .19 \\
\hline 12. Osobná bezpečnost' & -.09 & -.13 \\
\hline 13. Mat' zdroje moci & $.26^{* *}$ & .16 \\
\hline 14. Univerzalizmus tolerant. & .05 & .02 \\
\hline 15. Konformnost' - pravidlá & $-.28^{* *}$ & $-.32^{*}$ \\
\hline 16. Úspešnost' & $.26^{* *}$ & .17 \\
\hline 17. Zachovávanie tradícií & -.07 & -.13 \\
\hline 18. Vlastná akčnost' & -.03 & .08 \\
\hline 19. Zhovievavost' - starostlivost' & -.02 & .04 \\
\hline
\end{tabular}

Z výsledkov v tabul'ke 3 je evidentné, že rodové rozdiely majú na vzt’ah týchto premenných významný efekt: Extraverzia koreluje s výškou výdavkov na vol'ný čas iba u mužov ( $\mathrm{r}=.33)$. Zároveň sa ukázali ako signifikantné dve odlišné korelácie, ako to bolo bez zohl'adnenia rodu negatívna emocionalita $(\mathrm{r}=-.39)$ a frustrácia psychologických potrieb $(\mathrm{r}=-.38)$ korelujú významne negatívne s výškou výdavkov iba u mužov. V prípade žien je situácia iná: hedonizmus $(\mathrm{r}=.30)$, mat' zdroje moci $(\mathrm{r}=.26)$ a úspešnost' $(\mathrm{r}=.26)$ koreluje pozitívne s výškou výdavkov na vol'ný čas a chciet' sa zlepšovat' negatívne $(\mathrm{r}=-.21)$. Konformnost' koreluje s výdavkami $\mathrm{u}$ žien a mužov podobne $(\mathrm{r}=-.28$, resp. $\mathrm{r}=-32)$.

\section{Regresná analýza}

V realizovanom výskume u študentov boli tri psychologické charakteristiky - osobnost', motivácia a osobné hodnoty zist'ované pomocou 135 položiek (súčast'ou opytovania bolo d’alších 7 sociodemografických otázok, spolu 142 položiek). Takýto rozsah dotazníka je pre výskum v reálnej situácii v cestovnom ruchu problematický. V prípade študentov boli s výdavkami na vol'ný čas vo vzt’ahu iba niektoré zo psychologických charakteristík. Na základe toho bolo možné uvažovat' o redukcii rozsahu dotazníkov v budúcich výskumoch. Konkrétne, extraverzia a negatívna emocionalita majú po 12 položiek (spolu 24), frustrácia psychologických potrieb 9 položiek a hedonizmus, mat' zdroje moci, úspešnost', chciet' sa zlepšovat' a konformnost' majú po 3 položky (spolu 15). Aj ked' po tejto analýze je počet položiek podstatne menší, 48 položiek je pre výskumy výdavkov turistov cestovného ruchu stále nežiaduco vel'ký. Jednou z možností, ako počet položiek redukovat' bolo, zohl'adnit' fakt, že osobnostné premenné a motivácia sú tvorené facetami, resp. troma konkrétnymi psychologickými potrebami. Extraverzia je tvorená facetami - sociabilita, asertivita a energetická úroveň a Negatívna emocionalita - úzkost’ou, depresiou a emocionálnou nestálost'ou (každá faceta má 4 položky). Frustrácia sa vzt’ahuje na potrebu spolupatričnosti, kompetencie a autonómie (každá má po 3 položky). V d’alšej analýze sme využili možnost’ testovat' pomocou regresnej analýzy vzt'ahy psychologických charakteristík ako prediktorov a výšky výdavkov na vol’ný čas ako kritéria (závislá premenná) tak, že do 
regresných rovníc sme v prípade osobnosti a motivácie dosadili facety, resp. frustrované psychologické potreby a súčasne sme kontrolovali (do regresnej rovnice dosadené ako kovariát) efekt nevyhnutných výdavkov a prostriedkov, ktoré má osoba k dispozícii. Diferencované výsledky vzt’ahu psychologických charakteristík a výšky výdavkov na vol'ný čas z hl'adiska rodu bolo nevyhnutné zohl'adnit', preto boli výpočty realizované zvlášt' pre ženy a mužov. V tabul'ke 4a (ženy) a 4 b (muži) uvádzame výsledky výpočtov pre každú testovanú psychologickú charakteristiku v jednom riadku, kvôli rozsahu tabuliek neuvádzame celkové modely.

Tabul'ka 4a Psychologické charakteristiky ako prediktory výdavkov na vol’ný čas u žien

\begin{tabular}{llllll}
\hline Prediktory & $\mathrm{R}$ & $\mathrm{R}^{2}$-change & $\mathrm{b}$ & $\mathrm{T}$ & $\mathrm{p}$ \\
\hline Hedonizmus & .30 & $.09^{* *}$ & .37 & 2.752 & 0.007 \\
\hline Mat' zdroje moci & .26 & $.07 * *$ & .16 & 1.737 & n.s. \\
\hline Konformnost'-pravidlá & .28 & $.09^{* *}$ & -.28 & -2.458 & 0.016 \\
\hline Úspešnost' & .26 & $.07 * *$ & .20 & 1.667 & n.s. \\
\hline
\end{tabular}

Poznámka: *znamená $p<.05$, ** znamená $p<.01$, n.s. znamená nesignifikantné.

Čo sa týka žien (tabul'ka 4a), ked’že ani osobnost', ani motivácia u nich s výškou výdavkov na vol'ný čas nekorelovala, analyzovali sme preto iba 5 významne korelujúcich hodnôt. Hodnota Chciet' sa zlepšovat' v tabul'ke nie je, pretože v celkovom modeli bola nesignifikantná a zároveň ani jej percentuálny podiel na variancii výdavkov nebol signifikantný. Čo sa týka zvyšných štyroch hodnôt, hedonizmus a konformnost' zameraná na dodržiavanie pravidiel, mali aj po kontrole výšky nevyhnutných výdavkov a celkových prostriedkov signifikantný vzt'ah $\mathrm{k}$ výdavkom na vol'ný čas, mat' zdroje moci a úspešnost' signifikantné neboli, ale kvôli vel'kosti percenta vysvetlenej variancie sme ich aj v tabul'ke aj pre d'alší výskum ponechali: čím vyššie skóre v hedonizme $(b=.37)$, v hodnote mat' zdroje moci $(b=.16)$ a vyššie úsilie o úspešnost' $(b=$ $=.20$ ), tým vyššie výdavky na vol'ný čas, pričom hedonizmus vysvetlil 9\% variancie výdavkov, mat' zdroje moci a úspešnost' po 7 \%. Konformnost' zameraná na dodržiavanie pravidiel bola v inverznom vzt’ahu $\mathrm{k}$ výške výdavkov na vol’ný čas: čím vyššie skóre $(b=-.28)$, tým nižšie výdavky ( $9 \%$ variancie).

Tabul'ka 4b Psychologické charakteristiky ako prediktory výdavkov na vol'ný čas u mužov

\begin{tabular}{llllll}
\hline Prediktory & $\mathrm{R}$ & $\mathrm{R}^{2}$-change & $\mathrm{b}$ & $\mathrm{T}$ & $\mathrm{p}$ \\
\hline Sociabilita & .37 & $.13^{*}$ & .22 & 1.207 & $\mathrm{n} . \mathrm{s}$. \\
\hline Úzkost' & .46 & $.21^{* *}$ & -.41 & -1.477 & n.s. \\
\hline Spolupatričnost' - frustrácia & .32 & $.10^{*}$ & -.25 & -2.093 & 0.043 \\
\hline Autonómia - frustrácia & .37 & $.14^{*}$ & -.25 & -2.110 & 0.042 \\
\hline Konformnost'-pravidlá & .32 & $.10^{*}$ & -.48 & -2.142 & 0.038 \\
\hline
\end{tabular}

U mužov bola situácia odlišná (tabul'ka 4 b): dva osobnostné faktory (extraverzia a negatívna emocionalita) a jeden motivačný faktor (frustrácia 3 psychologických potrieb) signifikantne korelovali s výškou výdavkov na vol’ný čas, preto sme pomocou regresnej analýzy skúmali vzt'ah každého z troch facetov osobnosti a každej z troch frustrovaných potrieb v samostatných regresiách 
a podobne ako u žien, kontrolovali sme efekt nevyhnutných výdavkov a celkových prostriedkov. Ako je v tabul'ke 4 b vidiet', iba faceta sociabilita (extraverzia) a faceta úzkost' (negatívna emocionalita) mali vzt’ah k výške výdavkov na vol'ný čas, pričom neštandardizované regresné koeficienty neboli signifikantné, ale v tabul'ke sme obidva facety ponechali kvôli značnému podielu vysvetlenej variancie (13, resp. 21 \%): Č́m vyššia miera sociability, tým vyššie výdavky a čím vyššia miera úzkosti, tým nižšie výdavky. Čo sa týka frustrácie troch bazálnych psychologických potrieb, potreba kompetencie nebola v signifikantnom vzt'ahu k výdavkom na vol'ný čas, avšak frustrácia potreby spolupatričnosti a potreby autonómie áno: čím vyššia miera frustrácie obidvoch potrieb, tým nižšie výdavky. Podobný vzt’ah bol identifikovaný aj v prípade osobnej hodnoty konformnost' - dodržiavanie pravidiel, čím vyššie skóre v tejto hodnote, tým nižšie výdavky.

\section{Diskusia}

Výsledky výskumu troch relatívne stabilných psychologických charakteristík ako faktorov výdavkov na vol'ný čas u študentov možno zhrnút' takto: z troch charakteristík - osobnost' (5 osobnostných vlastností), motivácia (2 základné psychologické potreby) a osobné hodnoty (19 hodnôt ako motivujúcich ciel'ov) - celkom 26 analyzovaných psychologických charakteristík, ktoré boli zist'ované pomocou 135 položiek, iba čast' mala vzt’ah k výdavkom na vol'ný čas. Pričom tento vzt'ah bol odlišný u žien a mužov. Zatial' čo u žien boli dôležité štyri osobné hodnoty - hedonizmus, mat' zdroje moci, konformnost'-pravidlá a úspešnost', u mužov to bola sociabilita, úzkost', frustrácia potreby spolupatričnosti a potreby autonómie a hodnota konformnost'-pravidlá. Na základe výsledkov tejto analýzy sme predpokladali, že identifikované psychologické charakteristiky, ktoré majú vzt'ah k výdavkom na vol'ný čas u študentov, budú mat' vzt'ah k výške výdavkov turistov cestovného ruchu - návštevníkov športového podujatia. Do opytovania sme zaradili 4 hodnoty (12 položiek), 2 facety z osobnosti ( 8 položiek) a 2 frustrované potreby (6 položiek), spolu 26 položiek. Redukcia počtu položiek na základe výskumu u študentov z celkového počtu 135 na 26 položiek poskytla vhodný výskumný nástroj na účely výskumu u návštevníkov športového podujatia, u ktorých nemožno očakávat' ochotu odpovedat' na vel'ký počet otázok.

\section{B) Pilotný výskum faktorov výdavkov u návštevníkov športového podujatia}

V úvode k tomuto predvýskumu neuvádzame žiadne doterajšie zistenia ohl'adom vzt'ahu osobnosti, motivácie a osobných hodnôt k výške výdavkov turistov cestovného ruchu, pretože v dobe prípravy rukopisu takéto výskumy podl’a našich vedomostí neboli známe.

Ciel'om bolo overit' vzt’ah psychologických charakteristík k výdavkom, ktoré boli identifikované u študentov vysokých škôl. Boli očakávané diferencované vzt’ahy v závislosti od rodu: u žien budú mat' vzt'ah k výške výdavkov 4 osobné hodnoty (hedonizmus, mat' zdroje moci, konformnost'-pravidlá a úspešnost'), u mužov dve osobnostné vlastnosti (sociabilita a úzkost'), dve frustrované základné psychologické potreby (potreba spolupatričnosti a potreba autonómie) a jedna z osobných hodnôt (konformnost'-pravidlá). 


\section{Metóda}

Vzorka

Výskumný súbor tvorili návštevníci športového podujatia - MS v l'adovom hokeji 2019 v Košiciach, ktorí sa ubytovali v jednom z hotelov v Košiciach, resp. v Prešove. Aj ked’ do každého hotela bolo doručených po 200 dotazníkov, z celkového počtu 400 bolo vrátených 59 vyplnených. Jedna osoba odpovedala iba na čast' otázok, preto bola $\mathrm{z}$ analýzy vynechaná. $Z$ celkového počtu $\mathrm{N}=58$ návštevníkov podujatia bolo 46 zo zahraničia a 12 zo Slovenska, 18 žien a 40 mužov s priemerným vekom 41.6 roka (18-65 rokov). Priemerná dížka pobytu bola 4 prenocovania $(\mathrm{SD}=2.25$, rozpätie $1-12)$.

\section{Nástroje}

Okrem sociodemografických otázok bola zist'ovaná celková suma, ktorú účastník minul počas pobytu vrátane cesty, vstupeniek a bývania $(1=$ menej ako $300 €, 2=301-600 €, 3=601-900 €$, $4=901-1200 €, 5=1201-1500 €, 6=1501-1800 €, 7=$ viac ako $1801 €)$.

\section{Psychologické charakteristiky}

Štyri osobné hodnoty (hedonizmus, mat' zdroje moci, konformnost'-pravidlá a úspešnost'), dve osobnostné vlastnosti (sociabilita a úzkost'), dve frustrované základné psychologické potreby (potreba spolupatričnosti a potreba autonómie) boli zist'ované položkami, ktoré boli vybrané z dotazníkov opísaných v časti Nástroje v rámci výskumu u študentov. Otázky dotazníka boli pre zahraničných hostí preložené do anglického jazyka. Slovenská verzia bola najprv preložená do angličtiny odborníkom na preklad. Anglická verzia bola potom spätne preložená iným prekladatel'om do slovenčiny a vlastnosti spätného prekladu analyzovali autori výskumu. Finálnu verziu anglického prekladu korigoval d’alší prekladatel', ktorý plynule komunikuje anglicky.

\section{Realizácia výskumu}

So súhlasom vedenia hotelov boli dotazníky odovzdané na recepcii, prostredníctvom ktorej boli umiestnené na izby ubytovaných hostí. Po vyplnení ich zanechali pri odchode z hotela na určenom mieste.

\section{Výsledky}

Deskriptívna a korelačná analýza

Tabul'ka 5 Priemery (M), štandardné odchýlky (SD) a bivariantné korelácie výdavkov u žien (n= 18) a mužov $(n=40)$ so zist'ovanými psychologickými charakteristikami

\begin{tabular}{lcccccc}
\cline { 2 - 7 } & \multicolumn{7}{c}{ Celkové výdavky } \\
\cline { 2 - 7 } & $\mathrm{M}$ & $\mathrm{SD}$ & $\mathrm{r}$ & $\mathrm{M}$ & $\mathrm{SD}$ & $\mathrm{r}$ \\
\cline { 2 - 7 } & 40.89 & 10.25 & & 41.92 & 10.97 & \\
\hline Vek & 4.11 & 1.88 & - & 4.28 & 1.55 & - \\
\hline 1. Celkové výdavky & 3.72 & 0.89 & -.24 & 3.38 & 0.95 & .25 \\
\hline 2. Sociabilita & & & & & &
\end{tabular}




\begin{tabular}{lcccccc}
\hline 3. Úzkostnost' & 2.96 & 0.52 & -.32 & 3.04 & 0.56 & -.09 \\
\hline 4. Frustrácia p. spolupatričnosti & 2.72 & 1.13 & -.12 & 2.77 & 1.07 & $-.35^{*}$ \\
\hline 5. Frustrácia p. autonómie & 2.81 & 1.15 & -.01 & 3.07 & 1.02 & $-.35^{*}$ \\
\hline 6. Hedonizmus & 4.01 & 0.84 & -.10 & 4.13 & 1.13 & -.10 \\
\hline 7. Mat' zdroje moci & 2.65 & 0.94 & -.01 & 3.07 & 1.18 & -.22 \\
\hline 8. Konformnost' pravidlá & 3.63 & 1.02 & .21 & 3.50 & 0.85 & .11 \\
\hline 9. Úspešnost' & 3.09 & 0.97 & .18 & 3.05 & 1.12 & $-.31^{*}$ \\
\hline
\end{tabular}

V tabul'ke 5 sú uvedené základne deskriptívne údaje (M, SD) a korelácie psychologických charakteristík s celkovými výdavkami návštevníkov športového podujatia počas pobytu so zohl'adnením rodu. Očakávané vzt’ahy psychologických charakteristík a výšky výdavkov sa u žien nepotvrdili a u mužov čiastočne. Frustrácia potreby spolupatričnosti $(\mathrm{r}=-.35)$ a potreby autonómie $(r=-.35)$ ako motivačné premenné a hodnota úspešnost' ako ciel' $(r=-.31)$, korelovali signifikantne negatívne s výškou výdavkov: čím viac bola frustrovaná potreba spolupatričnosti a potreba autonómie, tým nižšia miera výdavkov a rovnako, čím viac bola osoba orientovaná na osobný úspech, tým nižšia miera výdavkov.

\section{Diskusia}

Skutočnost', že u žien neboli identifikované korelácie 4 hodnôt s výškou výdavkov možno interpretovat' dvojako: prvou príčinou bol nízky počet opytovaných osôb a druhou, s ktorou je v d'alších výskumoch potrebné počítat' je, že ani jedna zo zist'ovaných osobných hodnôt s výškou výdavkov na tento typ cestovného ruchu nekorešpondujú. V prípade mužov je situácia odlišná, aj tu možno uvažovat' o nízkom počte opytovaných osôb, avšak pri interpretácii sa dá položit' dôraz na to, že osobnostné premenné (sociabilita a úzkostnost') neovplyvňujú výšku výdavkov mužov pri cestovaní na návštevu športového podujatia. Pre mužov platí, že výška výdavkov je v negatívnom vzt'ahu $\mathrm{k}$ dvom frustrovaným potrebám - k potrebe spolupatričnosti a potrebe autonómie, a rovnako platí, že výška výdavkov je v negatívnom vzt’ahu k hodnotovej orientácii na dosahovanie úspechu.

\section{Celková diskusia a závery}

Brida a Scuderi (2013) na základe analýzy 86 štúdií, v ktorých identifikovali 50 faktorov výdavkov turistov cestovného ruchu rozdelených do 4 skupín (ekonomické, sociodemografické, typ cesty a psychografické) konštatovali, že: „Najprekvapujúcejším faktom ostáva zriedkavé využitie psychografických premenných...Oficiálne prieskumy zriedkavo priamo zistujú psychologické charakteristiky spotrebitel'a, čo môže byt' jedným z dôvodov ich obmedzeného využívania“" (str. 27). Pretože nebolo možné nadviazat' na existujúce výskumné zistenia, cielom tejto práce bol pokus o identifikáciu pravdepodobných psychologických faktorov v dvoch na seba nadväzujúcich výskumoch: po analýze výdavkov na vol’ný čas u študentov testovat' na malej vzorke efekt identifikovaných pravdepodobných prediktorov výdavkov u návštevníkov konkrétneho športového podujatia. Tento postup bol zvolený preto, lebo psychologické 
charakteristiky - osobnost', motivácia a osobné hodnoty sú v psychologickom výskume dobre definované, avšak na ich meranie sa využívajú nástroje s vel'kým počtom položiek a pre praktický výskum v oblasti cestovného ruchu ich možno považovat' za nepoužitel’né.

Čo sa týka výskumu výdavkov u študentov, bolo možné na základe realizovaných analýz identifikovat' malý počet psychologických charakteristík predikujúcich výšku výdavkov, a na základe toho redukovat' 135 otázok pôvodného dotazníka na konečných 26 . Vzt’ah identifikovaných charakteristík k výdavkom bol diferencovaný v závislosti od rodu: u žien to boli 4 osobné hodnoty (hedonizmus, mat' zdroje moci, konformnost'-pravidlá a úspešnost'), u mužov dve osobnostné vlastnosti (sociabilita a úzkost'), dve frustrované základné psychologické potreby (potreba spolupatričnosti a potreba autonómie) a jedna z osobných hodnôt (konformnost'-pravidlá).

Na to nadväzujúci predvýskum u návštevníkov športového podujatia, v ktorom boli použité iba identifikované psychologické charakteristiky a pomocou korelačnej analýzy bol overovaný ich vzt'ah k výške výdavkov, očakávané vzt’ahy u žien nepotvrdil. U mužov boli potvrdené čiastočne. Frustrácia potreby spolupatričnosti $(\mathrm{r}=-.35)$ a potreby autonómie $(\mathrm{r}=-.35)$ ako motivačné premenné a osobná hodnota zameraná na úspešnost' $(r=-.31)$, korelovali signifikantne negatívne s výškou výdavkov: čím viac bola u mužov frustrovaná potreba spolupatričnosti a potreba autonómie, tým nižšia miera výdavkov a rovnako, čím viac bola osoba orientovaná na osobný úspech, tým nižšia miera výdavkov.

Na základe uvedeného možno formulovat' tieto závery:

1) Podl'a doterajších štúdií, ak mikroekonometrické modely zahŕňali väčšinu z nasledujúcich premenných - ekonomické premenné (vel'kost' príjmu), sociodemografické premenné (vek, pohlavie, vzdelanie) a s pobytom súvisiace premenné, akými sú dížka pobytu, počet osôb v skupine, typ ubytovania, druh dopravy a vzdialenost' (napr. Thrane, 2014), tak OLS regresia vysvetl'ovala spravidla okolo 40 percent variancie výdavkov. Z uvedeného vyplýva, že ak má byt' model z hl'adiska predikcie efektívnejší, mali by nové premenné vysvetlit' inkrementálny prírastok variancie $\mathrm{k}$ existujúcim prediktorom. A ked’že ani jeden z vymenovaných prediktorov sa netýkal psychologických charakteristík turistov cestovného ruchu, inkrementálny prírastok by mohli vysvetlit' práve psychologické premenné. V našich dvoch predvýskumoch bolo očakávané, že skúmané relatívne stabilné psychologické charakteristiky osôb môžu prispiet' k zlepšeniu predikcie. Avšak osobnost', motivácia a osobné hodnoty tak, ako boli merané, u žien nemali žiadny a u mužov iba obmedzený negatívny vzt’ah k výdavkom návštevníkov športového podujatia. Na základe toho sa zdá, že testované premenné nie je vhodné považovat' za faktory, ktoré by mohli prispiet' $\mathrm{k}$ ich predikcii.

2) Vyššie uvedené konštatovanie nemusí znamenat', že je tomu tak vo vzt'ahu k všetkým typom cestovného ruchu. V iných typoch to môže byt' inak: napr. ak ide o kultúrny cestovný ruch (cultural tourism), slnenie a more (sun and sea tourism), plavba po mori (cruise tourism), príroda (nature tourism), vidiecky cestovný ruch (rural tourism), gastronomický (gastronomic tourism) a stretnutia-konferencie-výstavy (meeting, incentive, conferencing and exhibition, MICE tourism) (pozri Mudarra-Fernandéz et al., 2018). Autori uvádzajú aj deviatu kategóriu „iné kategórie cestovného ruchu“ (,other tourism categories"), do ktorej zahrnuli „health and beauty“, „,nautical tourism“, ,golf tourism“ a ,language-learning tourism“. Možno navrhnút', že v d'alších výskumoch bude vhodné zohl'adnit' napríklad špecifickost' osobných hodnôt a príslušného typu cestovného ruchu. V našom prípade, použitý dotazník osobných hodnôt nezis- 
t’oval orientáciu na osobnú hodnotu, akou je športovanie, ktorá by korešpondovala s návštevou športového podujatia.

3) Možno navrhnút' aj alternatívne vysvetlenie: dá sa predpokladat', že skúmané psychologické charakteristiky majú všeobecne nízku predikčnú silu vo vzt’ahu k výdavkom vo všetkých typoch cestovného ruchu, a preto je potrebné hl'adat' a v pilotnom výskume testovat' iné psychologické charakteristiky. Napríklad, ovel'a konkrétnejšou psychologickou charakteristikou, ktorá môže mat' vzt'ah k výške výdavkov, je šetrnost', resp. štedrost' ako osobná charakteristika.

Celkom na záver možno konštatovat', že psychologický výskum sa zatial' dostatočne neetabloval v oblasti cestovného ruchu. Ekonomický výskum v cestovnom ruchu „,narazil“ na potrebu poznat' psychologické faktory, avšak zatial' s nimi bud' nepracuje alebo pracuje, akoby osoba bola „black box“ (napr. Veisten et al., 2014, str. 302). Tri zvolené psychologické charakteristiky v našom predvýskume neboli vybrané na základe teórie, ale pragmaticky - na základe ich výskytu v literatúre publikovanej v oblasti cestovného ruchu. Pragmatickost' spočívala v tom, že išlo o snahu nájst' psychologické činitele, ktoré sú pre výskumníkov v tejto oblasti známe. Zatial' sa však táto stratégia ukázala ako neschodná. Pokus prezentovat’ teoretický model faktorov výdavkov v oblasti cestovného ruchu, ktorý by obsahoval psychologické faktory výdavkov, je zatial' odkázaný na výsledky d’alších predvýskumov.

\section{Grantová podpora}

Táto práca bola podporovaná Agentúrou na podporu výskumu a vývoja na základe zmluvy č. APVV-17-0166.

\section{Referencie}

Angelovič, M., \& Harizal, B. (2015). Výdavky študentov - kto míňa viac? Mladá věda - Young Science, 3(2), 25-39. Dostupné na: http://www.mladaveda.sk/portfolio-item/november-2015/

Ballantyne, R., Hughes, K., Lee, J., Packer, J., \& Sneddon, J. (2018). Visitors' values and environmental learning outcomes at wildlife attractions: Implications for interpretive practice. Tourism Management, 64, 90-201. https://doi.org/10.1016/j.tourman.2017.07.015

Baumeister, R. F. (2016). Toward a general theory of motivation: Problems, challenges, opportunities, and the big picture. Motivation and Emotion, 40(1), 1-10. https://doi.org/10.1007/ s11031-015-9521-y

Brida, J. G., \& Scuderi, R. (2013). Determinants of tourist expenditure: a review of microeconometric models. Tourism Management Perspectives, 6, 28-40. https://doi.org/10.1016/j. tmp.2012. 10. 006

Coppola, A., Verneau, F., Caracciolo, F., \& Panico, T. (2017). Personal values and prosocial behaviour. British Food Journal, 119(9), 1969-1982. https://doi.org/10.1108/BFJ-10-2016-0474

Cordeiro, P., Paixão, P., Lens, W., Lacante, M., \& Sheldon, K. (2016). Factor structure and dimensionality of the balanced measure of psychological needs among Portuguese high school students. Relations to wellbeing and ill-being. Learning and Individual Differences, 47, 51-60. https://doi.org/10.1016/j.lindif.2015.12.010 
Costa, P. T. Jr., \& McCrae, R. R. (1992). Four ways five factors are basic. Personality and Individual Differences, 13(6), 653-665. https://doi.org/10.1016/0191-8869(92)90236-I

Deci, E. L., \& Ryan, R. M. (2000). The "what" and the "why" of goal pursuits: Human needs and the self-determination of behavior. Psychological Inquiry, 11(4), 227-268. https://doi. org/10.1207/S15327965PLI1104_01

De Menezes, A. G., \& Moniz, A. (2011). Determinants of Length of Stay: A Parametric Survival Analysis. Tourism Analysis, 16, 1-16. https://doi.org/10.3727/10835421 0X12864727453106

Džuka, J. (2019). Factor structure of the Balanced Measure of Psychological Needs Scale (BMPN) among persons with incomes below the 'at-risk-of-poverty threshold'. Československá psychologie. Supplement, 1, 27-41. https://doi.org/10.1007/s11031-012-9279-4

Heung, V. C., Qu, H., \& Chu, R. (2001). The relationship between vacation factors and sociodemographic and travelling characteristics: the case of Japanese leisure travellers. Tourism Management, 22(3), 259-269. https://doi.org/10.1016/S0261-5177(00)00057-1

Hermannsson, K., McGregor, P., \& Swales, K. (2013). Consumption Expenditures in Economic Impact Studies: An Application to University Students, $53^{\text {rd }}$ Congress of the European Regional Science Association: ,Regional Integration: Europe, the Mediterranean and the World Economy“, 27-31 August 2013, Palermo, Italy, European Regional Science Association (ERSA), Louvain-la-Neuve.

Chen, K. H., Yu, P., Chang, F-H., \& Hsieh, Ch-L. (2014). Factors Influencing Taiwanese Backpakers Learning Travel: The Role of Personality Traits and Wellness Lifestyles. Tourism Analysis, 19, 199-212. https://doi.org/10.3727/108354214X13963557455720

Jalil, N. A., Yusof, H., Rambeli, N., Samsudin, N., \& Zakariya, Z. (2015). The Expenditure Behavior of the Economic Literates. International Business Education Journal, 8(1), 95-104.

Jani, D. (2014). Relating travel personality to Big Five Factors of personality. Tourism, 62(4), 347-359.

John, O. P., \& Srivastava, S. (1999). Big Five Trait Taxonomy. In L. Pervin, \& O. P. John (eds.), Handbook of Personality: Theory and Research ( $2^{\text {nd }}$ Ed.). New York: Guilford Publication.

Kahle, L. R. (1983). Social Values and Social Change: Adaptation to Life in America. New York: Praeger.

Karvonen, M., \& Komppula, R. (2013). Motivation based segmentation of Sulkava Rowing Race event visitors. Event Management, 17, 409-423. https://doi.org/10.3727/15259951 3X13769392444701

Kim, M. J., Bonn, M., Lee, Ch-Ki, \& Hahn, S. S. (2018). Effects of personality traits on visitors attending an exposition: the moderating role of anxiety attachment. Asia Pacific Journal of Tourism Research, 23(5), 502-519. https://doi.org/10.1080/10941665.2018.1468346

Li, M., \& Cai, L. A. (2012). The Effects of Personal Values on Travel Motivation and Behavioral Intention. Journal of Travel Research, 51(4), 473-487. https://doi. org/10.1177/0047287511418366

Lichy, J., \& McLeay, F. (2018). Bleisure: Motivations and Typologies. Journal of Travel and Tourism Marketing, 35(4), 517-530. https://doi.org/10.1080/10548408.2017.1364206

Lin, CH.-F., \& Fu, CH.-S. (2016). Changes in tourist personal values: impact of experiencing tourism products and services. Asia Pacific Journal of Tourism Research, 22(2), 173-186. https://doi.org/10.1080/10941665.2016.1208670 
Marcussen, C. H. (2011). Determinants of tourist spending in cross-sectional studies and at Danish destinations. Tourism Economics, 17, 833-855. https://doi.org/10.5367/te.2011.0068

Mudarra-Fernandéz, A. B., Carrillo-Hidalgo, I., \& Pulido-Fernández, J. I. (2019). Factorsinfluencing tourist expenditure by tourism typologies: a systematic review. Anatolia 30(1), 18-34. https://doi.org/10.1080/13032917.2018.1495086

Murray, E. (1964). Motivation and Emotion. Englewood Cliffs, NJ: Prentice Hall.

Sallahuddin, H., Zalila, O., Noor Sa'adah, S., Zalina, M. M., \& Mohamad, H. H. (2018). The Economic Impact of UUM International Students' Expenditure on Business Activities in Changlun. Journal of Social Studies Education Research, 9(1), 140-157. https://doi. org/10.17499/jsser.93983

Sheldon, K. M., \& Hilpert, J. C. (2012). The balanced measure of psychological needs

(BMPN) scale: An alternative domain general measure of need satisfaction. Motivation and Emotion, 36(4), 439-451. https://doi.org/10.1007/s11031-012-9279-4

Schwartz, S. H. (1992). Universals in the content and structure of values: Theory and empirical tests in 20 countries. In M. Zanna (ed.), Advances in experimental social psychology (s. 1-65). New York: Academic Press.

Schwartz, S. H., Vecchione, M., Fischer, R., Ramos, A., Dirilen-Gumus, D. O., Cieciuch... Konty, M. (2012). Refining the Theory of Basic Individual Values. Journal of Personality and Social Psychology, 103(4), 663-688. https://doi.org/10.1037/a0029393

Soto, C. J., \& John, O. P. (2017). The next Big Five Inventory (BFI-2): Developing and assessing a hierarchical model with 15 facets to enhance bandwidth, fidelity, and predictive power. Journal of Personality and Social Psychology, 113, 117-143. https://doi.org/10.1037/ pspp0000096

Tan, W.-K., \& Tang, CH.-Y. (2013). Does personality predict tourism information search and feedback behaviour? Current Issues in Tourism, 16(4), 388-406. https://doi.org/10.1080/1 3683500.2013 .766155

Thrane, C. H. (2014). Modelling micro-level tourism expenditure: recommendations on the choice of independent variables, functional form and estimation technique. Tourism Economics, 20(1), 51-60. https://doi.org/10.5367/te.2013.0254

Wang, Y., \& Davidson, M. C. G. (2010). A review of micro-analyses of tourist expenditure. Current Issues in Tourism, 13(6), 507-524. https://doi.org/10.1080/13683500903406359

Veisten, K., Lindberg, K., Grue, B., \& Haukeland, J. V. (2014). The role of psychographic factors in nature based tourist expenditure. Tourism Economics, 20(2), 301-321. https://doi. org/10.5367/te.2013.0281

Woosnam, K. M., Dudensing, R. M., \& Walker, J. R. (2015). How does emotional solidarity factor into visitor spending among Birders in the Lower Rio Grande Valley of Texas? Journal of Travel Research, 54(5), 645-658. https://doi.org/10.1177/0047287514522884

Zhang, H., \& Ren, Y. (2016). Research on the Consumer Market of College Students in Hebei Province. $3^{\text {rd }}$ International Conference on Education, Management, Arts, Economics and Social Science (ICEMAESS 2015).

Džuka, J., \& Štefko, R. (2019). Psychologické charakteristiky ako prediktory výdavkov turistov: predvýskum u študentov a pilotné overenie u návštevníkov športového podujatia. Psychologie a jeji kontexty, 10(2), 83-101. https://doi.org./10.15452/PsyX.2019.10.0015 